\title{
Peran Muhammad bin Salman terhadap Perubahan Pilar Kenegaraan Arab Saudi
}

\author{
Panji Haryadi \\ Program Studi Hubungan Internasional Universitas Pasundan \\ email: panjiharyadi627@gmail.com
}

\section{ABSTRACT}

Saudi Arabia has four pillars of the state, namely: Saud Family, Wahhabism, Oil, and Relationship with the United States. In 2017, Muhammad bin Salman (MbS) was appointed the crown prince by his father, Salman bin Abdulazis. Throughout the history of Saudi Arabia this has never happened, usually the crown prince is the brother of the ruling king. Another historical event is MbS took steps to change the three pillars. Changing pillars is a very high risk action, if it fails, the worst consequence is the collapse of the state.

Keywords: Saudi Arabia, the crown prince, Muhammad bin Salman, four pillars of Saudistate

\section{ABSTRAK}

Arab Saudi memiliki empat pilar kenegaraan, yaitu: Keluarga Saud, Paham Wahhabisme, Minyak, dan Relasi dengan Amerika Serikat (AS). Pada tahun 2017, Muhammad bin Salman (MbS) diangkat menjadi putra mahkota oleh ayahnya sendiri, Salman bin Abdulazis. Sepanjang sejarah Arab Saudi hal ini belum pernah terjadi, biasanya putra mahkota merupakan saudara laki-laki dari raja yang sedang berkuasa. Peristiwa bersejarah lainnya adalah MbS melakukan langkahlangkah untuk mengubah tiga dari empat pilar tersebut. Perubahan pilar negara merupakan sebuah tindakan yang sangat beresiko tinggi, apabila gagal, maka konsekuensi terburuknya adalah keruntuhan negara yang bersangkutan. 
Kata Kunci: Arab Saudi, putra mahkota, Muhammad bin Salman, empat pilar negara Saudi

\section{Pendahuluan}

Secara resmi Kerajaan Arab Saudi baru didirikan pada 23 September 1932, ketika kerajaan di wilayah Hijaz dan Najd disatukan. Kerajaan Arab Saudi menjadi penting bagi wilayah Timur Tengah yang mayoritas penduduknya beragama Islam, karena di tempat inilah dua kota suci agama Islam berada, yakni Mekah dan Madinah. Sepanjang sejarah kekhalifahan Islam, penguasaan atas dua kota suci ini menjadi semacam legitimasi bagi para penguasa Muslim, begitu pula bagi Kerajaan Arab Saudi. Nama kerajaan ini diambil dari nama keluarga penguasa setempat, yakni alSaud (Teitelbaum et.al, 2018).

Di era modern, Arab Saudi menjadi negara yang sangat diperhitungkan di Timur Tengah dan bahkan dunia, karena pengaruhnya yang sangat besar di kawasan. Dalam laporan versi tahun 2018 yang diterbitkan oleh US News \& World Report bekerjasama dengan The Wharton School The University of Pennsylvania, Arab Saudi diposisikan sebagai negara ke-9 terkuat di dunia. Sementara itu, dalam versi Forbes, apabila dilihat dari kawasan Timur Tengah, secara militer Arab Saudi menempati posisi ke-5 di Timur Tengah (Dudley, 2018). Sehingga, apapun yang terjadi di Arab Saudi akan mempengaruhi segala dinamika yang terjadi di Timur Tengah. Bukan hanya itu, dengan banyaknya negara super power yang turut bermain di kawasan, maka secara tidak langsung segala dinamika di Timur Tengah juga akan mempengaruhi konstelasi pada tingkat dunia.

Pendiri Kerajaan Arab Saudi era modern, sekaligus raja pertamanya adalah Abdulaziz bin Saud (berkuasa 1932-1953). Pada tahun 1953, ketika Abdulaziz bin Saud meninggal, tahta diteruskan kepada putra pertamanya yang bernama Saud bin Abdulaziz (berkuasa 1953-1964). Kemudian secara berturut-turut tahta diteruskan kepada anak-anak Abdulaziz yang lain, atau saudara laki-laki Saud bin Abdulaziz: Faisal bin Abdulaziz (berkuasa 1964-1975), Khalid bin Abdulaziz (berkuasa 19751982), Fahd bin Abdulaziz (berkuasa 1982-2005), Abdullah bin Abdulaziz (berkuasa 2005-2015), dan Salman bin Abdulaziz (2015-sekarang) (Chughtai, 2017).

Pada Januari 2015, setelah kematian raja sebelumnya, Abdullah, Salman secara resmi menjadi Raja Arab Saudi. Beberapa bulan kemudian, Salman menyingkirkan Muqrin bin Abdulaziz dari posisi putra mahkota, dia digantikan oleh Muhammad bin Nayef, keponakan Salman (Lightner, et al., 2017). Dengan perubahan ini, maka Salman 
telah membongkar tradisi lama Saudi yang biasanya menunjuk putra mahkota dari anak Abdulaziz bin Saud atau dari saudara laki-lakinya sendiri (Henderson, 2013). Untuk pertama kalinya dalam sejarah Arab Saudi, putra mahkota berasal dari cucu Abdulaziz bin Saud.

Kemudian pada tanggal 20 Juni 2017, Muhammad bin Nayef digantikan oleh Muhammad bin Salman (selanjutnya disingkat MbS), putra kandung Salman. Dengan demikian, kembali terjadi peristiwa pertama dalam sejarah Saudi, seorang anak dari raja yang berkuasa menjadi putra mahkota. MbS adalah putra ke-7 Salman dari istri ketiganya yang bernama Fahda binti Falah bin Sultan Al Hithalayn. Keputusan Salman didukung oleh 31 dari 43 anggota komisi suksesi Arab Saudi (Christiastuti, 2017).

MbS kemudian melakukan serangkaian kebijakan internal. Pertama, ia melakukan penangkapan terhadap sejumlah pangeran dengan tuduhan korupsi, termasuk di antaranya Walid bin Talal, orang terkaya di Timur Tengah, dan Mitab bin Abdallah, komandan 100.000 pasukan al-Haras al-Watanī, divisi militer khusus pelindung kerajaan (Detik, 2017). Kedua, ia melakukan perlawanan terhadap paham ekstrem dengan cara menangkapi sekitar 20 ulama yang dianggap ekstremis, termasuk imam terkemuka, Salman al-Odah dan Awad al-Qarni (Kompas, 2017). Ketiga, ia melakukan perubahan dalam kebijakan ekonomi kerajaan dengan mencetuskan konsep Visi 2030. Poin penting dalam Visi 2030 adalah diversifikasi ekonomi sehingga minyak bumi diharapkan tidak lagi menjadi sumber pendapatan utama Saudi. Saat ini, 90\% pendapatan Arab Saudi bergantung terhadap minyak dan gas (Doucet, 2017). Untuk memenuhi target Visi 2030, pemerintah Arab Saudi membutuhkan dana sebesar \$ 500 miliar atau sekitar Rp 6.700 triliun (The Economist, 2017).

Berbagai kebijakan yang diambil Pangeran Muhammad bin Salman tak pelak lagi telah membawa perubahan terhadap empat pilar Kerajaan Arab Saudi, yaitu klan (dinasti) Bin Saud, ajaran Wahhabisme, minyak, dan relasi dengan AS (Stenslie, 2018). Dalam artikel ini, penulis akan mendeskripsikan keempat pilar tersebut dengan menggunakan kerangka teoritis yang dikemukakan Barry Buzan mengenai keamanan.

\section{Kerangka Teoritis}

Secara teoritis empat pilar Kerajaan Arab Saudi ini dapat dijelaskan oleh teori yang dikembangkan oleh Barry Buzan mengenai keamanan. Di dalam bukunya yang berjudul People, State, and Fear, Buzan menjelaskan bahwa terdapat empat macam tipe ancaman terhadap keamanan, yaitu: militer, politik, ekonomi, dan ekologi (Buzan, 1983: 75-83). 
Militer adalah ancaman keamanan paling tradisional, dan memiliki efek yang paling fatal terhadap setiap komponen negara. Serangan militer bahkan dapat menghancurkan suatu negara karena setiap sendi-sendi penyokong negara seperti politik, ekonomi, dan sosialnya juga turut serta hancur. Maka, tidak mengherankan apabila suatu negara menempatkan kemampuan militernya sebagai fokus utama keamanannya.

Politik. Secara esensial negara sebenarnya adalah entitas politik. Secara internal, ide-ide, informasi, dan institusi politik di dalam sebuah negara saling berkontestasi secara dinamis untuk membangun negara. Namun di luar itu, politik juga rentan terhadap ide-ide politik yang kontradiktif, yakni ideologi yang menjadi antitesa dari ideologi yang sudah ada. Oleh karena itu, ancaman politik pun seringkali sama-sama ditakuti sebagaimana ancaman militer, karena datangnya suatu ide politik, maka konsekuensinya adalah menghilangkan yang lainnya.

Ekonomi, adalah ancaman keamanan yang paling sulit dihubungkan dengan keamanan nasional apabila dibandingkan dengan militer ataupun politik. Sebab, dalam kondisi normal pun, di tengah persaingan dan ketidakpastian, maka ekonomi pun sudah cukup beresiko. Ekonomi tentu saja sesuatu hal yang bersifat material, namun di baliknya terdapat juga unsur ideologi dan institusi yang mengelolanya.

Ekologi atau lingkungan hidup bukanlah suatu ancaman yang diakibatkan karena bencana alam yang sifatnya natural seperti banjir, gempa, badai, dan lain sebagainya. Ancaman ekologi yang dimaksud adalah ancaman yang diakibatkan oleh aktivitas manusia, baik itu dilakukan di dalam negeri sendiri maupun berasal dari negeri orang, misalnya saja polusi. Secara umum, ancaman ekologi ini tidak menjadi prioritas yang harus ditanggulangi, namun dalam kasus-kasus tertentu, hal ini bisa jadi menjadi prioritas, misalnya ancaman efek rumah kaca dan mencairnya kutub bumi.

Khusus mengenai masalah ekologi, artikel ini tidak akan membahasnya. Saudi memang memiliki beberapa isu lingkungan hidup seperti ketersediaan sumber air bersih, emisi gas buang, dan limbah pengolahan minyak. Namun pemerintah Saudi sendiri tidak melihat ini sebagai persoalan prioritas (Fanack, 2009).

\section{Empat Pilar Kerajaan Arab Saudi}

Perubahan besar sosioekonomi dan demografi yang telah dilalui kerajaan Arab Saudi seiring dengan berlalunya waktu, ditambah dengan terjadinya gerakan revolusi politik di TimurTengah yang disebut dengan Arab Spring, Dinasti Saud secara 
argumentatif dapat dikatakan sebagai rezim yang paling stabil di Timur Tengah. Banyak peneliti yang mengaitkan bahwa kestabilan ini didapat dari pilar-pilar yang menyokong tegaknya negara Arab Saudi. Menurut Stenslie (2018), konstruksi kerajaan Saudi bergantung pada empat pilar, yaitu: pertama, kunci bertahannya keluarga Saudi adalah kemampuan mereka untuk menyatukan berbagai klan di dalam keluarga kerajaan; kedua, legitimasi Wahhabisme, yaitu sebuah aliran dalam Islam yang memberikan legitimasi kekuasaan selama berabad-abad terhadap keluarga Saud; ketiga, hasil penjualan minyak yang amat besar yang digunakan oleh keluarga Saud untuk "menghidupi" para pendukungnya; dan keempat, hubungan dengan Amerika Serikat (AS) yang telah memberikan jaminan keamanan kepada rezim Saudi.

\section{Keluarga Saud}

Kekuatan kunci dari rezim Saud selama berabad-abad adalah kemampuan mereka untuk menyatukan berbagai klan. Meskipun terjadi berbagai friksi dan perseteruan, mereka memiliki tujuan bersama yaitu mempertahankan kekuasaan Dinasti Saud (Henderson, 1995:6).

Keluarga Saud memiliki sejarah yang panjang sebelum akhirnya memiliki kekuasaan yang menjelma dalam bentuk negara. Pada tahun 1744, Muhammad bin Saud, anak dari seorang penguasa padang pasir di Diriyah (sekarang berada di dekat Riyadh, ibu kota Arab Saudi), menikahi putri dari seorang pembaharu agama yang bernama Muhammad bin Abdul Wahhab. Di kemudian hari aliran agama yang didirikan oleh Muhammad bin Abdul Wahhab dikenal dengan sebutan Wahhabi dan menjadi paham yang paling dominan di Arab Saudi (Gearon, 2016:224). Hasil dari pernikahan inilah yang kemudian menjadi cikal bakal dari rezim Saud yang kini berkuasa di Arab Saudi modern. Para anak keturunan Muhammad bin Saud dan Muhammad bin Abdul Wahhab terus berkembang dan menciptakan sejumlah klan di dalam Dinasti Saud. Klan-klan inilah yang menjadi kunci dari bertahannya Dinasti Saudi selama berabad-abad. Pada pertengahan tahun 1970-an, anggota keluarga klan-klan ini diperkirakan mencapai sekitar 20.000 orang (Henderson, 1995:6).

Beberapa klan besar keturunan Muhammad bin Saud yang memiliki pengaruh kuat di antaranya adalah Al Saud Al Kabir, Bani Jiluwi, Al Turki, Thunayyan, dan Al Farhan. Di luar itu ada klan lainnya yang disebut dengan al-Sheikh, yaitu sebuah klan yang secara keturunan lebih kuat dari garis Muhammad bin Abdul Wahhab. Secara tradisional al-Sheikh selalu menghasilkan anggota keluarga yang menjadi ulama 
yang seringkali menempati posisi penting di dalam kerajaan di bidang hukum dan pendidikan, baik sebagai menteri maupun anggota dewan agama tertinggi kerajaan. Sampai hari ini mereka tersebar di berbagai departemen sipil, keamanan, dan militer Arab Saudi. Ibu dari Raja Faisal (Raja Arab Saudi ke-3, berkuasa 1964-1975) juga merupakan seorang al-Sheikh (Henderson, 1995:6-7).

Klan besar lainnya adalah Al Sudairi yang didirikan Ahmad bin Muhammad Al Sudairi, seorang pendukung Abdulaziz bin Saud di awal-awal pembentukan Kerajaan Arab Saudi. Ahmad bin Muhammad AI Sudairi menikahkan putrinya yang bernama Hassa dengan Abdulaziz bin Saud. Darinya, Abdulaziz mendapatkan tujuh anak lelaki, dua di antara mereka di kemudian hari menjadi Raja Arab Saudi, yaitu Fahd bin Abdulaziz (berkuasa 1982-2005), dan Salman Bin Abdulaziz (2015-sekarang) (Henderson, 1995:7). Ketujuh anak lelaki Abdulaziz, yaitu Fahd, Sultan, Abdurrahman, Nayef, Turki, Salman, dan Ahmad, terkenal dengan sebutan "Sudairi Tujuh" dan menjadi faksi tersendiri yang sangat kuat di tengah kerajaan. Sementara itu, anggota keluarga keturunan Al Sudairi lainnya sampai hari ini menempati berbagai posisi penting di pemerintahan (Helfont, 2015).

Pada tahun 1953, ketika Abdulaziz bin Saud meninggal, tahta diteruskan kepada putra pertamanya yang bernama Saud Bin Abdulaziz (berkuasa 1953-1964). Kemudian secara berturut-turut tahta diteruskan kepada anak-anak Abdulaziz yang lain, atau saudara laki-laki Saud Bin Abdulaziz: Faisal Bin Abdulaziz (berkuasa 19641975), Khalid Bin Abdulaziz (berkuasa 1975-1982), Fahd Bin Abdulaziz (berkuasa 1982-2005), Abdullah Bin Abdulaziz (berkuasa 2005-2015), dan Salman Bin Abdulaziz (2015-sekarang) (Chughtai, 2017). Tidak seperti tradisi kerajaan-kerajaan lainnya di dunia yang menunjuk anak dari raja untuk menjadi putra mahkota, tradisi suksesi raja di Saudi diturunkan kepada adik laki-laki dari raja sebelumnya (Henderson, 1995:7).

Di era Salman, yang menjadi putra mahkota adalah Muqrin bin Abdulaziz, anak termuda dari Abdulaziz bin Saud. Ketika Abdulaziz masih hidup, dia mengakui Muqrin sebagai putranya. Namun setelah Abdulaziz meninggal, saudara-saudara tiri Muqrin menggugat asal-usulnya yang beribukan orang Yaman, yang artinya bukan keturunan Muhammad bin Saud dan Muhammad bin Abdul Wahhab. Tuduhan lainnya adalah bahwa status ibu Muqrin bukanlah istri sah (Henderson, 1995:7).

Abdulaziz pernah mengatakan bahwa seorang raja seharusnya bukan anak orang asing. Di antara 22 istri Abdulaziz, sebagian besarnya bukan orang Arab sehingga jumlah anak yang memenuhi syarat untuk menjadi raja menjadi berkurang. Ibu dari Bandar bin Abdulaziz adalah orang Maroko, sedangkan ibu dari Muqrin dan Hidhlul 


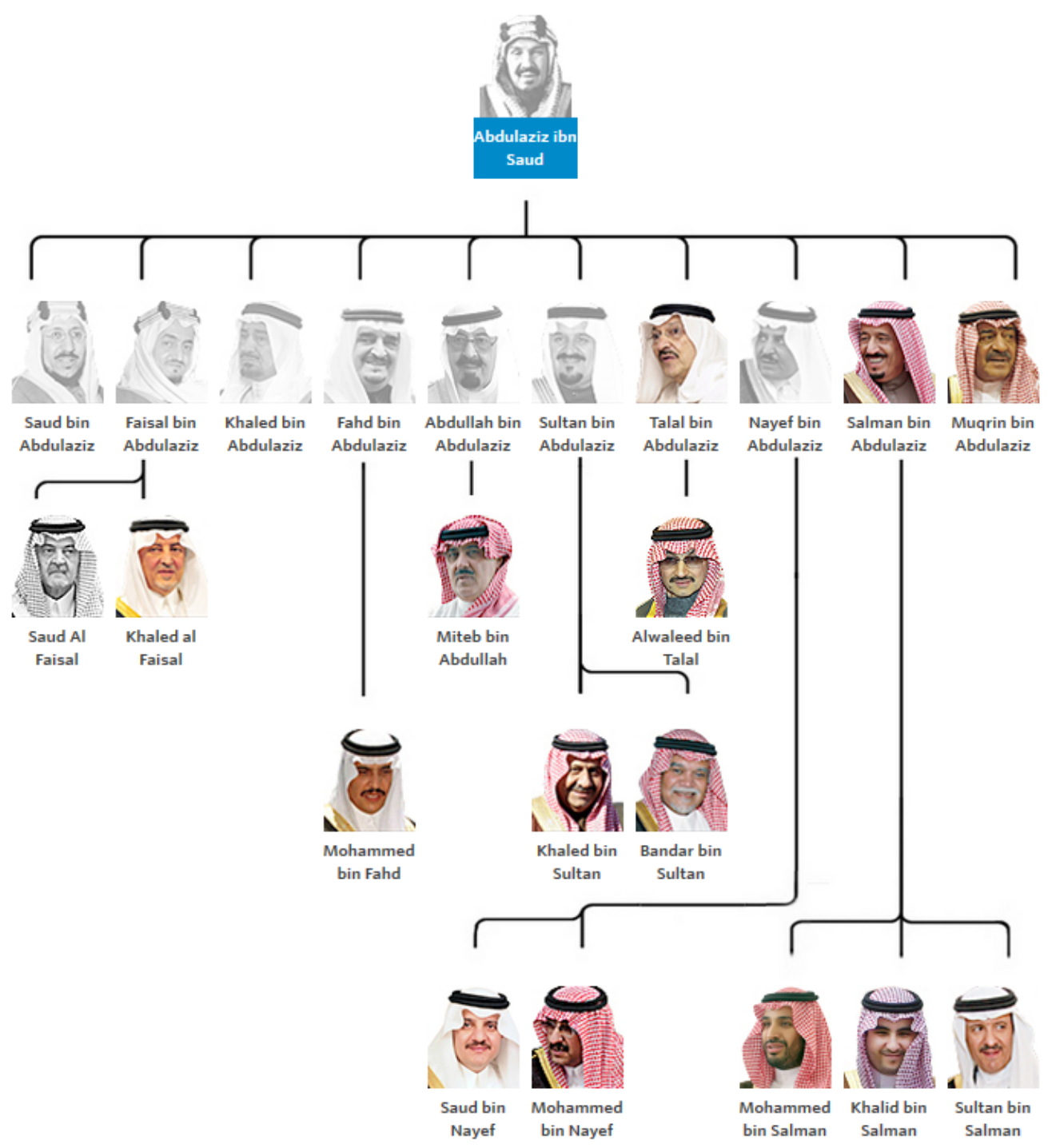

Keluarga Kerajaan Arab Saudi. Sumber: The Washington Post, http://graphics.wsj.com/ saudi-arabia-family-tree/

adalah orang Yaman. Sementara itu ibu dari Mishal, Mitab, Talal, dan Nawaf adalah orang Armenia (Henderson, 2009:11).

Lemahnya posisi Muqrin membuat Raja Salman leluasa mencopot jabatannya sebagai putra mahkota dan menunjuk Muhammad bin Nayef, keponakan Salman yang berasal dari klan Sudairi. Dan setelah itu, Salman membuat manuver lanjutan, mengangkat putranya sendiri, MbS sebagai putra mahkota dengan menggeser Muhammad bin Nayef. Sebelum diangkat menjadi putra mahkota pada 21 Juni 2017, MbS, sudah menarik perhatian dunia internasional karena perannya yang begitu besar dalam dinamika pemerintahan kerajaan Arab Saudi. Dia dipercaya memegang jabatan-jabatan strategis dalam pemerintahan ayahnya, di antaranya 
Menteri Pertahanan, Ketua Dewan Urusan Ekonomi dan Pembangunan, dan Wakil Perdana Menteri.

MbS juga diyakini sebagai tokoh utama di balik agresi Arab Saudi ke Yaman dan perseteruan Arab Saudi dengan Qatar. Selain itu, pada 25 April 2016 dia mencetuskan reformasi ekonomi Arab Saudi yang disebut dengan Visi 2030. Oleh media-media Barat, karena kekuasaan MbS di kerajaan Arab Saudi mencakup begitu banyak hal, ia dijuluki Mr. Everything. Dengan demikian, secara faktual, meskipun MbS masih berstatus sebagai putra mahkota, dia sudah memerintah sebagaimana Raja Arab Saudi (Langer, 2017).

Setelah diangkat menjadi putra mahkota, MbS meluncurkan program "perang melawan korupsi" dan menahan sebelas pangeran, empat menteri, serta puluhan mantan menteri dengan tuduhan korupsi. Mereka bukan hanya ditangkap, melainkan juga dibekukan aset kekayaannya, dicopot jabatannya, serta dipermalukan di depan umum. Hal ini berbeda dengan tradisi Dinasti Saud dimana meski sebagian pangeran tidak diberi posisi penting, kesejahteraan mereka dijamin. Tindakan keras MbS memunculkan prediksi adanya upaya pembalasan dendam terhadap MbS (Stenslie, 2018:69-70).

Untuk saat ini, kampanye anti-korupsi MbS cukup populer di kalangan warga Saudi, terutama kelas menengah ke bawah yang muak dengan para elit yang menyalahgunakan kekuasaan dan memperkaya diri sendiri. MbS telah menggunakan kampanye anti-korupsi untuk menampilkan dirinya sebagai Robin Hood Arab yang mengambil dari orang kaya dan memberi kepada orang miskin. Beberapa petinggi kerajaan yang ditangkap telah membayar sejumlah besar uang kepada kas negara sebagai imbalan kebebasan mereka. Pangeran Miteb bin Abdullah dilaporkan dibebaskan setelah setuju membayar sebanyak 1 miliar US Dollar dan secara total diperkirakan kas negara bertambah 50-100 miliar US Dollar ((Stenslie, 2018: 75). Namun demikian, di saat yang sama MbS memperlihatkan gaya hidup yang mewah, seperti membeli kapal pesiar terbesar dunia, Serena, seharga 550 juta US Dollar (2016); membeli chateau Perancis seharga 300 juta US Dollar (2017); serta membeli lukisan Salvator Mundi seharga 450 juta US Dollar (2017).

Sebagaimana dikemukakan Stenslie (2018) bahwa pilar Kerajaan Arab Saudi adalah persatuan Dinasti Saud, kinerja Raja Salman dan putranya, MbS terlihat kontraproduktif dengan upaya menjalin persatuan. Mereka telah menyusun sebuah skenario sistematis yang menempatkan MbS menjadi penguasa tunggal. Sistem kekuasaan tunggal seperti ini lebih mudah untuk dijatuhkan dalam sebuah revolusi, 
ketimbang ketika kekuasaan disebar ke lingkungan keluarga yang lainnya (Stenslie, 2008: 64).

Apabila dikaitkan dengan teori Buzan (Buzan, 1983:76-77), perilaku MbS merupakan ancaman politik, sebab dia hendak merobohkan tatanan persatuan keluarga Saud, yang sebelumnya merupakan entitas politik yang solid menjadi sistem kekuasaan tunggal yang otoriter. Secara umum, dinasti Saud memang dinasti yang otoriter terhadap warganya, namun itu semua bersifat institusional, namun kali ini otoriterianisme dilakukan oleh seorang penguasa tunggal, baik terhadap keluarga Saud maupun kepada warga Arab Saudi sendiri.

\section{Paham Wahhabisme}

Ulama telah memainkan peran penting sepanjang sejarah Dinasti Saud. Pada era-era awal pembentukan dinasti ini, yaitu ketika Muhammad bin Saud dan Muhammad bin Abdul Wahhab memutuskan beraliansi pada 1744, mereka merencanakan sebuah jihad untuk menaklukkan dan memurnikan tanah Arab dari bid'ah. Doktrin mereka adalah bahwa siapapun yang tidak menerima ajaran Islam menurut penafsiran Wahhabi, dia harus dibunuh atau dipaksa pergi meninggalkan tanah Arab (Henderson, 1995:2). Doktrin ini terinspirasi dari ajaran Ibnu Taimiyah (1263-1328) yang menyatakan bahwa negara Islam yang ideal mesti didirikan oleh dua otoritas yang sejajar, yaitu: pangeran dan ulama. Pangeran ditugaskan untuk memerintah, sementara ulama ditugaskan untuk mengawasi bagaimana jalannya politik (Stenslie, 2018:65).

Aliansi Muhammad bin Saud dan Muhammad bin Abdul Wahhab melakukan kampanye penaklukan ke berbagai suku-suku Arab dan terus berlanjut ketika Muhammad bin Saud meninggal pada tahun 1765. Abdul Wahhab melanjutkan perang terhadap berbagai suku Arab dengan dibantu oleh putra Muhammad bin Saud, Abdulaziz bin Muhammad. Mereka akhirnya menguasai sebagian besar wilayah pusat Arab yang dikenal sebagai Najd, termasuk kota Riyadh. Abdul Wahhab meninggal pada tahun 1792, tetapi Abdulaziz bin Muhammad tetap melanjutkan ekspansinya hingga ke Irak (1802) dan Mekah (1803). Usai penaklukan Mekah, Abdulaziz pun dibunuh (Henderson, 1995:2). Namun demikian, Dinasti Saud terus berkuasa di Mekah dan Madinah, sampai akhirnya digulingkan oleh Imperium Ottoman pada 1820 (Gearon, 2016:230).

Pasca kekalahan ini, seorang ulama Wahhabi bernama Sulaiman bin Abdallah Al al-Sheikh (cucu dari Abdul Wahhab) menulis doktrin baru Wahhabisme yaitu al- 
Dala'il fi Hukm Muwalat Ahl al-lshrak yang menyatakan bahwa seorang Muslim yang menunjukkan kesetiaan terhadap orang-orang musyrik akan tergolong ke kaum kafir, dan yang dimaksud sebagai kaum kafir adalah orang-orang Ottoman. Dengan demikian, doktrin Wahhabi yang semula berfokus pada ajaran fiqih (larangan melakukan bid'ah) bertambah dengan doktrin politik (mengenai kesetiaan kepada penguasa Muslim) (Wagemakers, 2012:95).

Pada 1824, Dinasti Saud kembali mengambil alih kekuasaan di tanah Arab, namun akhirnya direbut oleh Muhammad bin Rashid pada akhir abad ke-19; sampai kemudian Dinasti Saud berkuasa lagi pada 1932. Menyikapi hal ini, ulama-ulama Wahhabi selanjutnya mengembangkan doktrin menekankan kepatuhan kepada pemimpin. Doktrin ini berbunyi la din illa bi-jamaa wa-la jama'a illa bi-imama wala imama illa bi-sam wa-ta'a (tidak ada agama kecuali melalui jamaah, tidak ada jamaah kecuali melalui kepemimpinan, dan tidak ada kepemimpinan kecuali melalui mendengarkan dan kepatuhan) (Wagemakers, 2012:95).

Dengan demikian, meminjam istilah Wagemakers (2012), ada dua jenis doktrin Wahabbisme, yaitu Wahhabi Sosial dan Wahhabi Politik. Wahhabi Sosial adalah sikap yang lebih memilih diam dan taat apabila terkait urusan dengan pemerintah/ pemimpin, fokus mereka hanya kepada penyebarluasan ajaran Wahhabi di masyarakat; sementara Wahhabi Politik adalah sikap kritis terhadap urusan pemerintah/kenegaraan.

Trend yang berkembang saat ini di Kerajaan Arab Saudi adalah Wahhabi Sosial. Meskipun demikian, secara formalitas mereka masih dilibatkan dalam suksesi kepemimpinan. Berdasarkan kesepakatan, raja Saudi yang baru bergantung kepada sumpah setia pangeran lainnya untuk mengkonfirmasi posisinya. Setelah proses itu dilalui, para ulama kemudian harus mendeklarasikan raja yang baru itu sebagai seorang Imam. Deklarasi ini hanya dapat dilakukan atas dasar fatwa bahwa suksesi itu sah. Persetujuan dari para ulama ini bukan hanya untuk mengukuhkan bahwa suksesi itu dilandasi atas dasar agama, tetapi juga berfungsi sebagai pengingat bahwa di antara Keluarga Saud dan Wahhabi secara historis memiliki hubungan yang sangat dekat (Henderson, 1995:15).

Secara teoritis, para ulama sebetulnya memiliki hak untuk memilih pemimpin yang berada di luar garis keturunan Saud yang dominan, tetapi pada faktanya hal tersebut tidak pernah terjadi. Para ulama yang diberikan hak untuk mengeluarkan fatwa tergabung dalam Dewan Tinggi Agama, dan mereka dipilih oleh raja. Maka siapapun ulama yang berada di dalamnya, mereka tidak pernah memiliki pendapat 
yang independen, pengaruh anggota keluarga Saud senior di sana masih sangat besar (Henderson, 1995:16).

Perkembangan selanjutnya adalah terjadinya penentangan dari kalangan Wahhabi Politik terhadap Rezim Saud. Antara lain, pada awal tahun 1990-an, Osama bin Laden mendirikan al-Qaeda setelah pecah aliansi dengan Raja Fahd yang dipicu oleh keputusan Fahd mengizinkan pasukan Barat untuk hadir di tanah Arab dalam Perang Teluk. Dalam pandangan Osama, tanah Arab adalah tanah suci yang tidak boleh dimasuki oleh orang-orang kafir. Osama mengatakan bahwa kehadiran militer AS di Arab Saudi terlalu dekat dengan Mekah, dan itu merupakan provokasi bagi dunia Muslim (Yusufzai, 2001).

Osama didukung oleh ulama Wahhabi yang telah terpengaruh oleh ide-ide Ikhwanul Muslimin dari Mesir. Gerakan ini disebut dengan al-Sahwa al-Islamiyyah (Kebangkitan Islam) atau lebih terkenal dengan sebutan Sahwa. Tokoh-tokoh ulama terkemukanya adalah Salman al-Oudah, Oudh al-Qarni, Rarm al-Bishi, dan Ali Omari. Gerakan Sahwa berhasil ditumpas oleh pihak kerajaan, ribuan dari mereka menjadi tahanan politik, dan pada tahun 2003 banyak di antara mereka ditahan atas tuduhan terlibat dalam aktivitas teroris (Lacroix, 2011). Kini, Sahwa dinyatakan sebagai organisasi terlarang di Saudi, dan banyak di antara anggotanya yang mengubah pandangannya menjadi moderat. Ekstrimisme kelompok Wahhabi Politik kembali muncul pada masa Salman bin Abdulaziz ketika ribuan warga Saudi diidentifikasi telah bergabung dengan ISIS (Islamic State of Iraq and al-Sham) (Stenslie, 2018:72-73).

Putera Mahkota Muhammad bin Salman dalam sebuah wawancara dengan The Guardian pada Oktober 2017, mengatakan bahwa dia berjanji untuk mengembalikan Arab Saudi ke "Islam moderat" dan meminta dukungan global untuk mengubah kerajaan Saudi yang berhaluan garis keras menjadi masyarakat terbuka yang memberdayakan warga dan memikat para investor. MbS juga mengatakan bahwa Arab Saudi telah menjadi negara ultra-konservatif dalam 30 tahun terakhir, dan menurutnya itu bukan hal yang normal. Dia menuduh bahwa lahirnya doktrindoktrin kaku dari ulama terhadap masyarakat adalah sebagai reaksi dari revolusi Iran. Menurut MbS, raja-raja sebelumnya tidak tahu bagaimana menghadapinya.

“Kita hanya kembali pada apa yang kita ikuti - (yaitu) Islam moderat (yang) terbuka terhadap dunia dan semua agama. 70\% orang Saudi lebih muda dari 30 tahun, sejujurnya kita tidak akan menyia-nyiakan 30 tahun kehidupan kita untuk melawan pemikiran ekstremis, kita akan menghancurkan mereka sekarang dan segera," kata MbS (Chulov, 2017). 
Meskipun Sahwa secara praktis telah dilucuti oleh pihak kerajaan, pada faktanya MbS masih cukup khawatir dengan gerakan Wahhabi Politik. la pun memerintahkan aparat Arab Saudi untuk menangkap lebih dari 20 imam dan kaum intelektual, termasuk Salman Al Oudah dan Oudh AI Qarni, tokoh Sahwa. Al Oudah dulunya pernah ditangkap dan dipenjarakan oleh pihak kerajaan pada tahun 1994-1999. Pada tahun 2012, al-Oudah pernah menerbitkan buku yang berjudul PertanyaanPertanyaan Tentang Revolusi, yang menantang prinsip kesetiaan kepada penguasa dan mengklaim bahwa ada jalan tengah antara kesetiaan dan pemberontakan dengan kekerasan, yakni dengan revolusi damai. Buku itu dilarang beredar oleh pemerintah Saudi namun Al Oudah tetap menyampaikan ide-idenya lewat media sosial. la memiliki 14 juta follower di Twitter, mayoritasnya anak muda, sehingga membuat pihak kerajaan melihatnya sebagai ancaman (Stenslie, 2018:72-73).

Tidak hanya menyasar ranah Wahhabi Politik, MbS juga 'menyerang' Wahhabi Sosial melalui serangkaian kebijakan yang dapat mengubah tatanan kultural masyarakat Arab Saudi secara revolusioner. Sebelumnya Kerajaan Arab Saudi dikenal memiliki tafsir yang ultra-konservatif terhadap ajaran Islam tentang perempuan, antara lain kewajiban mengenakan jubah panjang dan longgar (abaya) saat berada di depan umum; larangan bergaul dengan pria yang tidak memiliki hubungan saudara; serta larangan menyetir mobil.

Untuk menegakkan aturan tersebut, polisi syariah yang disebut dengan mutawa berpatroli dan melakukan hal-hal yang dalam perspektif Hak Asasi Manusia versi Barat bisa dikategorikan sebagai pelanggaran berat. Misalnya saja, mutawa berhak memberhentikan laki-laki dan perempuan yang sedang melaju dalam kendaraan, serta patroli di mal, restoran, dan tempat umum lainnya untuk mencari tahu apakah laki-laki dan perempuan yang sedang bersama sudah menikah atau belum, atau apakah mereka punya hubungan saudara atau tidak. Kini, atas arahan MbS, sejak tahun 2016 mutawa tidak diizinkan mengejar orang-orang di jalan atau meminta untuk melihat identitas seseorang atau dokumen lain. Mereka juga dilarang menjebak atau menangkap orang (Associated Press, 2016).

Pada tanggal 26 September 2017, pemerintah Arab Saudi mengeluarkan izin mengemudi bagi kaum perempuan. Mereka juga diizinkan bergabung dengan militer dan dinas intelijen, serta datang ke arena olahraga. Selain itu, Saudi juga mulai membangun bioskop-bioskop di seluruh penjuru negeri (Chulov, 2018). Saudi juga merencanakan membangun kota hiburan ala Disney Land di Qiddiya, di dekat Riyadh, lengkap dengan taman hiburan Six Flags, taman air, fasilitas olahraga motor, even-even budaya, dan pemukiman untuk berlibur (Kalin and Rashad, 2018). 
Aturan berpakaian kaum perempuan pun dilonggarkan oleh ulama Saudi. Tradisi abaya dan jilbab hitam bagi perempuan Saudi merupakan produk dari fatwa ulama Wahhabi terdahulu yang tergabung dalam Sahwa. Namun akhirnya pada Februari 2018, Sheikh Abdullah al-Mutlaq, seorang anggota Dewan Ulama Senior, mengatakan bahwa para wanita Muslim harus berpakaian sopan, tetapi bukan berarti harus mengenakan abaya (Reuters, 2018). Dalam sebuah wawancara eksklusif dengan jurnalis AS Norah O'Donnell, MbS mengatakan, “Hukumnya sangat jelas dan ditetapkan dalam hukum syariah, bahwa perempuan (harus) mengenakan pakaian yang pantas dan terhormat, seperti laki-laki. Ini, bagaimanapun, tidak secara spesifik menyebutkan abaya hitam atau penutup kepala hitam. Keputusan sepenuhnya diserahkan kepada perempuan untuk memutuskan" (Lemon, 2018).

Manuver MbS dalam bidang politik maupun sosial, terutama terkait dengan kaum perempuan, telah melampaui batas-batas ajaran puritanisme khas Wahhabi, baik Wahhabi Politik maupun Wahhabi Sosial. Perubahan yang drastis ini diprediksi akan membawa resiko, antara lain, jika ulama Wahhabi Sosial ditekan secara berlebihan mereka mungkin saja bertransformasi menjadi Wahhabi Politik dan melakukan aksiaksi politik melawan kekuasaan Dinasti Saud.

Sejak awal, pakta Saud-Wahhab merupakan suatu kesatuan, mereka tumbuh besar bersama dengan perannya masing-masing. Apabila Wahhabi politik di masa lalu memang sudah pernah diberantas oleh keluarga Saud, lain halnya dengan Wahhabi sosial, mereka baru dilucuti di era MbS. Praktis, apabila ini dilanjutkan, maka Wahhabi bisa jadi tidak memiliki peran apa-apa lagi, dan ini merupakan ancaman terhadap entitas politik tradisional (Buzan, 1983:76-77) Arab Saudi yang tidak disukai golongan ulama beserta pengikutnya.

\section{Minyak}

Pada tahun 1938, perusahaan AS, Chevron, menemukan minyak di bawah gurun pasir Saudi, dan selama Perang Dunia II berlangsung, produksi minyak berkembang pesat. Namun, pendapatan Saudi dari minyak yang terbesar baru terjadi pada tahun 1973-1974 ketika dunia Barat mengalami krisis minyak (EIA, 2018). Hal ini dipicu oleh perang Arab-Israel, waktu itu negara-negara Arab yang tergabung dalam Organization of Petroleum Exporting Countries (OPEC) melakukan embargo minyak terhadap AS dan beberapa negara Barat lainnya karena mendukung Israel. Akibatnya, harga minyak dunia meroket hingga mencapai empat kali lipat dari harga normal (www.history.state.gov). 
Dilihat dari sumber ladang minyak yang sudah ditemukan, Arab Saudi memiliki hampir seperlima dari cadangan minyak dunia. Dengan sumber daya sebesar itu, Saudi menjadi negara pengekspor minyak terbesar dan penghasil minyak terbesar kedua di dunia (EIA, 2018).

Arab Saudi dapat dikatakan sebagai rentier state terbesar di dunia, yakni sebuah negara yang pendapatan nasionalnya sepenuhnya atau sebagian besarnya berasal dari sumber daya alam lokal. Pendapatan utama kerajaan berasal dari penjualan minyak dan investasi luar negeri (yang modalnya berasal dari penjualan minyak). Hanya sebagian kecil saja pendapatan yang berasal dari pajak dan retribusi. Kerajaan menggunakan sebagian hasil minyak itu untuk menjamin kenyamanan materi warga negara dan sebagai imbalannya, warga diharuskan untuk menerima hak penguasa untuk memerintah. Sistem ini juga diistilahkan dengan authoritarian bargain (tawarmenawar penguasa otoriter) (Stenslie, 2018:66).

Pada 2014, Arab Saudi menghadapi krisis akibat anjloknya harga minyak, dari 114 dollar/barrel menjadi di bawah 30 dollar/barrel. Pada tahun-tahun selanjutnya harga minyak naik turun, namun tidak pernah mencapai pada posisi aman. Kondisi mengancam kestabilan ekonomi Arab Saudi. Pada tahun 2030, diperkirakan sebanyak 4,5 juta pemuda Saudi akan memasuki usia angkatan kerja. Jumlah itu hampir dua kali lipat dari jumlah total orang Saudi yang bekerja hari ini. Inilah yang melatarbelakangi perumusan konsep "Visi 2030" yang berisi rancangan diversifikasi ekonomi untuk melepaskan ketergantungan Arab Saudi terhadap minyak. MbS dalam upanya mengimplementasikan Visi 2030 telah melakukan dua langkah ekstrem, pertama, menyingkirkan fatwa-fatwa ulama yang dianggap menghambat, misalnya terkait hak-hak perempuan Arab Saudi, karena untuk mencapai Visi 2030, kaum perempuan Saudi harus produktif dan menjadi mitra sejajar dengan laki-laki sehingga bisa ikut serta secara aktif memajukan negara (Mashuri, 2017). Kedua, dia menyingkirkan pangeran-pangeran lainnya dengan tuduhan korupsi.

Selain itu, MbS mendirikan mega-kota bisnis seluas 26.500 kilometer persegi dan dengan garis pantai sepanjang $468 \mathrm{~km}$ yang diberi nama NEOM [=baru/masa depan]. Kota bisnis ini akan beroperasi secara otonom, tidak terikat oleh peraturan Kerajaan Arab Saudi sebagaimana wilayah lainnya. Gambaran NEOM di masa depan adalah sebuah wilayah yang dioperasikan dengan teknologi tingkat tinggi dan akan menjadi "rumah" bagi orang-orang yang memiliki keterampilan kelas dunia dalam industri bioteknologi dan makanan (Kinninmont, 2017: 9-10). 


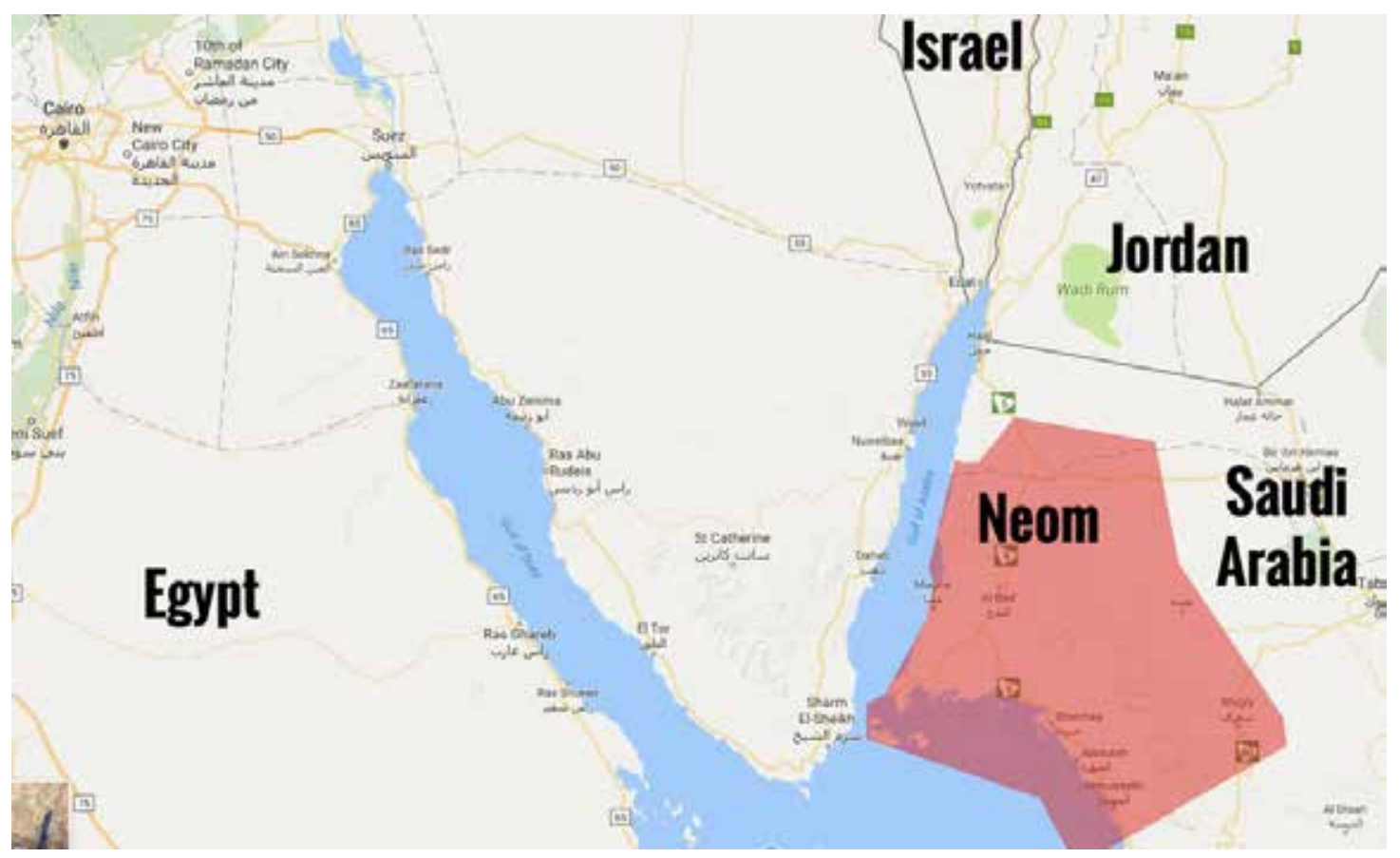

Peta lokasi NEOM. Sumber: New Atlas, https://newatlas.com/neom-saudi-arabia-future-megacity/51893/\#p488188

NEOM mendapatkan dukungan dari pebisnis global, seperti Masayoshi Son, CEO dari Softbank Jepang. Softbank sudah menginvestasikan \$ 93 miliar dari total sekitar \$100 miliar yang akan dinvestasikan, di sektor listrik tenaga surya, robot, dan teknologi artificial intelligence. NEOM juga didukung Stephen Schwarzman, kepala Blackstone, raksasa ekuitas swasta; dan Klaus Kleinfeld, mantan kepala Arconic, Alcoa dan Siemens yang akan menjadi kepala eksekutif NEOM. Dengan motto NEOM "tempat yang paling aman, paling efisien, paling berorientasi pada masa depan, dan tempat terbaik untuk tinggal dan bekerja", pemerintah Arab Saudi cukup optimis mencanangkan mengalirnya investasi senilai \$ 500 miliar atau sekitar Rp 6.700 triliun (The National, 2017).

Namun demikian, terdapat tiga pertanyaan skeptis mengenai NEOM. Pertama, waktu; yaitu akankah proyek mampu mengumpulan dana dengan cepat sehingga mendapatkan momentum yang sempurna? Sejauh ini, detail dan waktunya tetap samar- samar. Pemerintah mengatakan bahwa dana $\$ 500$ miliar akan tiba pada "tahun-tahun mendatang". Namun, penurunan harga minyak sejak tahun 2014 telah menekan keuangan publik: pada tahun 2017 pemerintah Arab Saudi menjalankan defisit fiskal sebesar 9\% dari PDB dan ekonomi Arab Saudi jalan di tempat. Kedua, dapatkah NEOM menghasilkan kreativitas dengan pola bottom-up agar dapat mengimbangi Visi 2030 yang dibuat dengan pola top-down? Ketiga, dapatkah NEOM 
menjadi magnet internasional bagi SDM yang berkualitas (termasuk perempuan)? Untuk dapat mewujudkannya kerajaan Arab Saudi mesti menjamin bahwa NEOM akan menjadi tempat yang ramah dan terbuka, tidak seperti tradisi puritan yang selama ini dikenal (The National, 2017). Apapun jawabannya, masa depan Dinasti Saud akan tetap bergantung pada bagaimana mereka mampu mengelola minyak, atau bagaimana mereka mencari alternatif selain minyak.

Buzan mengklasifikasikan, bahwa negara yang bergantung terhadap sumber daya alamnya, apalagi minyak, merupakan negara yang paling rentan terhadap ancaman ekonomi, sebab segala pondasi penyokong berlangsungnya negara ini bergantung terhadap minyak, yang mana apabila minyak ini hilang, maka akan mempunyai efek secara langsung terhadap kondisi sosial-politik negara tersebut. Dalam kasus Saudi, efek lain dari ketiadaan minyak adalah berkurangnya kemampuan militer yang selama ini dibiayai oleh minyak (Buzan, 1983:79, 81).

\section{Hubungan dengan Amerika Serikat}

ArabSaudi dan Amerika Serikat memiliki hubungan saling ketergantungan. Faktor paling dominan dalam hubungan itu adalah faktor minyak, keamanan, dan Islam. AS membutuhkan sumber minyak yang dapat diandalkan, sebaliknya rezim Saud membutuhkan keamanan dan dukungan politik. Mengenai Islam, khususnya versi Wahhabi, di satu sisi AS mendorong agar Saudi terus memelihara akar tradisionalnya (yaitu Wahhabisme), namun di sisi lain AS juga harus memastikan bahwa agar paham Wahhabi tidak mengganggu kekuasaan keluarga Saud (Henderson, 1995:39).

Selain itu, Saudi merupakan mitra penting ekonomi AS. AS merupakan pemasok barang impor terbesar ke kerajaan Saudi selama bertahun-tahun, terutama perangkat militer. Pada tahun 1994, total pesanan perangkat militer Saudi ke AS berjumlah lebih dari \$ 30 miliar, jumlah yang sangat besar untuk waktu itu, bahkan Saudi diragukan sanggup untuk membayarnya. Pada masa itu, yang tadinya hubungan kerjasama AS dengan Saudi didominasi oleh perusahaan-perusahaan minyak, beralih kepada perusahaan-perusahaan militer yang memasok peralatan dan sistem keamanan, beserta teknologi dan juga tenaga ahlinya (Henderson, 1995:39-40). Berdasarkan laporan dari The Stockholm International Peace Research Institute (SIPRI), Arab Saudi adalah pembeli $25 \%$ dari total penjualan senjata AS ke seluruh dunia pada periode 2013-2018. Penjualan senjata terbesar AS ke Saudi sejak tahun 1990 terjadi di masa pemerintahan Presiden Obama (Dehghan, 2018). 
Bagi AS, hubungan terpentingnya dengan Saudi adalah urusan ekonomi, sementarabagiSaudi,yang terpenting adalah persoalan keamanan. Selama bertahuntahun Saudi telah mendefinisikan konsep keamanan mereka dalam berbagai jalan, namun apapun itu, pada prinsipnya fokus utama pemikiran mereka selalu berpusat pada perasaan takut karena dikepung oleh negara-negara musuh, sebagaimana pernah diungkapkan oleh Abdulaziz sendiri pada tahun 1948 (Henderson, 1995:40). Pada saat itu, hal yang dipandang sebagai ancaman terbesar bagi Saudi adalah komunisme dan gerakan radikal dari dalam negeri. Kini, tiga ancaman terbesarnya datang dari Irak, Iran, dan Yaman.

Pasca revolusi Iran pada tahun 1979, yang berlanjut dengan Perang Teluk 1990, Invasi AS ke Irak pada tahun 2003, serta invasi Arab Saudi terhadap Yaman sejak tahun 2015, Saudi memandang dirinya dikepung oleh negara musuh. Menghadapi situasi ini, Saudi telah memutuskan bahwa satu-satunya negara yang dapat memberikan jaminan keamanan yang memadai adalah AS, yang sejauh ini memang bersedia melakukannya. Setiap presiden AS dari mulai Truman sampai Bush telah memberikan komitmen keamanan secara lisan kepada Arab Saudi untuk menjamin integritas teritorialnya. Arab Saudi nyatanya cukup puas dengan komitmen ini, para pemimpin Saudi juga telah mengakomodasi komunitas ekspatriat AS dalam jumlah besar di lingkungan kerajaan - termasuk penasehat militer yang jumlahnya sangat banyak - untuk bertindak sebagai penjamin keamanan negara tersebut (Henderson, 1995:40-41).

Pada masa Raja Salman, hubungan AS-Saudi semakin intens. Presiden Trump melakukan kunjungan luar negeri pertamanya ke Arab Saudi, bukan ke tetangga terdekatnya seperti Kanada atau Meksiko. Dalam kunjungan tersebut, pejabat senior Saudi mengatakan bahwa Trump "mengirim pesan yang jelas bahwa AS berdiri dengan sekutu dekatnya di wilayah tersebut dan bahwa mereka tidak meninggalkan kami" (Bayoumi and Paul, 2017). Setelah MbS diangkat menjadi putra mahkota, Trump secara eksplisit memberikan dukungannya kepada MbS, "Saya pikir ayahmu membuat keputusan yang sangat bijaksana" (TRT World, 2018).

Hubungan Arab Saudi dengan AS adalah satu-satunya pilar kenegaraan Saudi yang tidak diubah oleh MbS. Segala langkah MbS terhadap AS tampak sinergis dengan apa yang telah dilakukan oleh raja-raja sebelumnya. Para pengamat mengatakan bahwa antara Trump dan anggota keluarga kerajaan Saudi memiliki sejumlah kesamaan yang mencolok: mereka beroperasi dengan cara yang sama, keduanya memiliki anggota keluarga sebagai penasihat yang paling tepercaya, mereka mencampur kepentingan publik dan pribadi, dan hak asasi manusia bukan 
topik pembicaraan yang mereka sukai (Stenslie, 2018:76). Administrasi Trump telah berulang kali memberikan dukungan politik yang relatif tanpa pamrih ke Arab Saudi. Antipati terhadap Iran adalah masalah yang pertama dan terutama yang menyatukan Washington dan Riyadh. Sementara itu Saudi telah bekerja sama dengan aliansi negara-negara Sunni serta Israel untuk melawan apa yang mereka tafsirkan sebagai kekuatan Iran yang berkembang. Trump sendiri menginginkan penghapusan perjanjian nuklir dengan Iran (Stenslie, 2018:76).

Dukungan AS tidak diragukan lagi telah mendorong adventurisme diplomatik dan militer Saudi di Timur Tengah. Trump telah menyatakan dukungan kepada Arab Saudi dalam konflik yang sedang berlangsung dengan Qatar, meskipun Qatar merupakan tuan rumah pangkalan militer AS yang terbesar di TimurTengah. Dengan izin Trump, Arab Saudi telah mengintensifkan perangnya diYaman, menyebabkan apa yang Jan Egeland, Sekretaris Jenderal Dewan Pengungsi Norwegia, katakan sebagai "krisis kemanusiaan terbesar di dunia" (Egeland, 2017). PBB juga menyatakan hal yang serupa, dengan 22 juta orang (sepertiga dari populasi Yaman) yang menderita karena membutuhkan bantuan dan perlindungan, menurut Sekretaris Jenderal PBB, Antonio Guterres, Yaman telah jatuh ke dalam "krisis kemanusiaan terburuk di dunia" (Nikbakht dan Mc.Kenzie, 2018).

Ketergantungan Saudi terhadap kekuatan militer AS, merupakan sebuah respon terhadap perasaan takut akan kepungan negara-negara tetangga yang mungkin menyerang mereka secara militer. Oleh Buzan, perilaku seperti ini dikategorikan sebagai respon terhadap ancaman militer (Buzan, 1983:75-76). Khusus mengenai Iran, persepsi ancaman bukan hanya militer saja, namun juga ideologis (Buzan, 1983:76-77).

\section{Kesimpulan}

Naiknya MbS sebagai putra mahkota Arab Saudi telah membawa sangat banyak perubahan dalam lingkungan keluarga Saud. Meskipun masih berstatus sebagai putra mahkota pada faktanya dia sudah memimpin Arab Saudi bagaikan raja. Dari empat pilar Arab Saudi: Keluarga Saud, Ulama Wahhabi, Minyak, dan Relasi dengan AS, MbS telah merombaknya, dari empat itu, hanya satu yang dia pertahankan, yakni Relasi dengan AS.

Empat pilar ini, dari sejak awal-awal pendirian Arab Saudi, telah menjadi pondasi struktur kerajaan. Ketika MbS melakukan perombakan besar, ini bukannya tanpa resiko, kerajaan Arab Saudi menjadi tidak stabil dan resisten. Tidak ada yang dapat 
menjamin keberlangsungan negara Arab Saudi dengan perombakan sebesar itu. Jika MbS berhasil melaksanakan agenda-agendanya, maka Arab Saudi akan berubah bentuk menjadi despotisme yang sesungguhnya. Arab Saudi di bawah kekuasaan MbS tidak akan menjadi sebuah negara yang memiliki kekuatan komunitas dan sosial. Arab Saudi akan dipandang hanya sebagai individu. Kemudian kerajaan Saudi juga akan menjadi negara yang menolak segala macam hak dan keinginan warganya yang seharusnya bisa diekspresikan kepada perwakilan lembaga pemerintahan.

Di saat negara lainnya sedang bertransformasi ke arah demokrasi, Saudi malah mundur ke belakang. Dengan kata lain, MbS akan menjadi perwujudan dari negara itu sendiri, dan setiap warganya akan kehilangan setiap suara apapun, baik secara tradisional maupun modern. MbS telah menempatkan dirinya menjadi penguasa tunggal, dan dengan sistem seperti ini, negara lebih mudah untuk dijatuhkan dalam sebuah revolusi. Stig Stenslie mengatakan, skenario terburuk dari perubahan besar ini adalah runtuhnya Kerajaan Arab Saudi. Jika Saudi runtuh, maka akan ada konsekuensinya, baik itu secara: lokal, regional, maupun global.

Secara lokal, jika rezim jatuh, negara itu kemungkinan besar akan runtuh dan populasi masyarakatnya akan terbagi atas dasar kepemilikan geografis, pembagian suku, dan sektarian, sebagaimana hal ini pernah terjadi berabad-abad sebelumnya di Arab Saudi sebelum keluarga Saud berkuasa. Berbagai macam kelompok akan bertarung satu sama lain untuk mendapatkan kekuasaan dan sumber daya, terutama atas cadangan minyak yang sangat luas di negara itu. Besar kemungkinan kelompokkelompok teroris seperti ISIS dan al-Qaeda akan berusaha untuk menguasai Mekah dan Madinah, situs tersuci umat Islam. Sebab, doktrin khilafah mereka mengatakan bahwa legitimasi kekhalifahan di antaranya adalah penguasaan terhadap kota suci.

Secara regional, keruntuhan Arab Saudi akan membawa konsekuensi bagi wilayah Timur Tengah lainnya. Ada bahaya bahwa negara monarki lainnya di Semenanjung Arab - seperti Kuwait, Bahrain, Qatar, dan Uni Emirat Arab - akan terpengaruh, dan trend revolusi akan terjadi di masing-masing negara. Selain itu, tekanan akan semakin meningkat terhadap rezim yang bergantung pada dukungan keuangan dari Arab Saudi, termasuk Mesir dan Yordania. Kemudian, gudang sistem persenjataan modern Arab Saudi bisa saja jatuh ke tangan teroris — dan itu akan menjadi ancaman bagi seluruh kawasan.

Secara global, kejatuhan keluarga Saud akan memiliki dampak internasional yang besar, harga minyak dunia akan melambung tinggi, dan itu dapat memicu resesi ekonomi global. Intervensi militer internasional untuk mengamankan ladang 
minyak, dan mungkin juga kota-kota suci, juga tidak dapat dikecualikan. Misalnya saja Iran, yang selama ini sering mengatakan bahwa pengelolaan ibadah haji semestinya tidak dimonopoli oleh Arab Saudi, melainkan seharusnya dikelola oleh negara-negara Islam, karena Mekah adalah milik umat Islam.

\section{Daftar Pustaka}

Bayoumy, Y. dan Paul, K. (2017). Trump to reassure Saudi allies, promote business, talk tough on radicalism. Reuters [online]. Dalam: https://www.reuters.com/article/ us-usa-trump-saudi-analysis/trump-to-reassure-saudi-allies-promote-businesstalk-tough-on-radicalism-idUSKCN18C2QO [Diakses 10 Juni 2018].

Christiastuti, N. (2017). Anak Raja Salman Diangkat Jadi Putra Mahkota Arab Saudi. Detik, [online] Dalam: https://news.detik.com/internasional/d-3537654/anakraja-salman-diangkat-jadi-putra-mahkota-arab-saudi [Diakses 24 Mei 2018].

Chughtai, A. (2017). Line of succession to Saudi Arabia's throne. Aljazeera, [online Dalam: $\quad$ https://www.aljazeera.com/indepth/interactive/2017/06/line succession-saudi-arabia-throne-170621175317617.html [Diakses 21 Mei 2018].

Chulov, M. (2017). I will return Saudi Arabia to moderate Islam, says crown prince. The Guardian, [online] Dalam: https://www.theguardian.com/world/2017/oct/24/iwill-return-saudi-arabia-moderate-islam-crown-prince [Diakses 5 Juni 2018].

Chulov, M. (2018). Saudi Arabia's new mood: more freedom for women - but is the nation ready? The Guardian, [online]. Dalam: https://www.theguardian.com/ world/2018/mar/03/saudi-arabia-new-mood-freedom-for-women-but-is-itready [Diakses 6 Juni 2018].

Dehghan, S. (2018). Nearly half of US arms exports go to the Middle East. The Guardian, [online]. Dalam: https://www.theguardian.com/world/2018/mar/12/nearly-halfof-us-arms-exports-go-to-the-middle-east [Diakses 10 Juni 2018].

Detik. (2017). Arab Saudi Tahan Pangeran, Menteri, Pebisnis, Apa yang Terjadi? [online] Dalam: $\quad$ https://news.detik.com/bbc/3717807/arab-saudi-tahan-pangeranmenteri-pebisnis-apa-yang-terjadi [Diakses 25 Mei 2018].

Doucet, L. (2017). Is Saudi Arabia on the cusp of change?. BBC, [online]. Dalam: http:// www.bbc.com/news/world-middle-east-38951539 [Diakses 31 Mei 2018]. 
Dudley, D. (2018). The 10 Strongest Military Forces In The Middle East. Forbes, [online]. Dalam: https://www.forbes.com/sites/dominicdudley/2018/02/26/tenstrongest-military-forces-middle-east/\#61 c0607216a2 [Diakses 21 Mei 2018].

Egeland, J. (2017). Yemen Is Already the World's Largest Humanitarian Crisis -We Cannot Be Complicit in the Strangling of a Nation. Telegraph, [online] Dalam: https://www.telegraph.co.uk/news/2017/12/06/yemen-already-worlds-largesthumanitarian-crisis-cannot-complicit/ [Diakses 14 Juni 2018].

EIA (The U.S. Energy Information Administration). (2017). Total Petroleum and Other Liquids Production - 2017. [online] Dalam: https://www.eia.gov/beta/ international/index.cfm?topL=exp, [Diakses 14 Juni 2018].

Fanack. (2009). Saudi Arabia. [online] Dalam: https://fanack.com/saudi-arabia/ geography/ [Diakses 14 Juni 2018].

Gearon, E. (2016). Turning Points in Middle Eastern History. Virginia: The Great Courses

Helfont, T. (2015). The Sudairi Seven Back on Top. [online] Dalam: https://www.fpri. org/2015/01/the-sudairi-seven-back-on-top/ [Diakses 23 Mei 2018].

Henderson, S. (1995). After King Fahd: Succession In Saudi Arabia. The Washington Institute for Near East Policy: Policy Papers Number 37.

Henderson, S. (2013). Who Will Be the Next King of Saudi Arabia?. [online] Washington Institute. Dalam: http://www.washingtoninstitute.org/policy-analysis/view/ who-will-be-the-next-king-of-saudi-arabia [Diakses 22 Mei 2018].

History.state.gov. Oil Embargo, 1973-1974. [online] Dalam: https://history.state.gov/ milestones/1969-1976/oil-embargo [Diakses 7 Juni 2018].

Kalin, S., dan Rashad, M. (2018). Saudi Arabia launches multi-billion dollar entertainment resort. Reuters, [online]. Dalam: https://www.reuters.com/article/ us-saudi-qiddiya-ceo/saudi-arabia-launches-multi-billion-dollar-entertainmentresort-idUSKBN1HZOWF [Diakses 6 Juni 2018].

Kinninmont, J. (2017). Vision 2030 and Saudi Arabia's Social Contract: Austerity and Transformation. Research Paper: Middle East and North Africa Programme.

Kompas. (2017). Arab Saudi Tangkapi Imam-imam yang Dianggap Membangkang. [online] Dalam: https://internasional.kompas.com/read/2017/09/14/22115841/ 
arab-saudi-tangkapi-imam-imam-yang-dianggap-membangkang [Diakses 25 Mei 2018].

Lacroix, S. (2011). Saudi Islamists and the potential for protest. [online] Foreign Policy. Dalam: http://foreignpolicy.com/2011/06/02/saudi-islamists-and-the-potentialfor-protest/ [Diakses 4 Juni 2018].

Langer, M. (2017). Saudi Arabia's Mohammed bin Salman: Reformer and hard-liner. DW, [online]. Dalam: http://www.dw.com/en/saudi-arabias-mohammed-binsalman-reformer-and-hard-liner/a-40714307 [Diakses 10 Mei 2018].

Lemon, J. Everything you need to know about Saudi crown prince's first U.S. TV interview. [online] Stepfeed. Dalam: https://stepfeed.com/everything-you-need-to-knowabout-saudi-crown-prince-s-first-u-s-tv-interview-7031 [Diakses 6 Juni 2018].

Lightner, R., Al Omran, A., dan Rivas, A. (2015). Saudi Arabia's Royal Family. Wall Street Journal, [online] Dalam: http://graphics.wsj.com/saudi-arabia-family-tree/ [Diakses 23 Mei 2018].

Mashuri, I. (2017). Saudi tak Lagi Mengekspor Wahabi?. Republika, [online]. Dalam: https://www.republika.co.id/berita/kolom/resonansi/17/11/06/oyyiz5440saudi-tak-lagi-mengekspor-wahabi [Diakses 10 Juni 2018].

Reuters. (2018). Long robes not necessary attire for Saudi women: senior cleric. [online] Dalam: https://www.reuters.com/article/us-saudi-women/long-robes-notnecessary-attire-for-saudi-women-senior-cleric-idUSKBN1FUOHN [Diakses 6 Juni 2018].

Stenslie, S. (2018). The End of Elite Unity and the Stability of SaudiArabia. The Washington Quarterly: Spring.

Teitelbaum, J., Philby, H., dan Ochsenwald, W. (2018). Saudi Arabia. [online] Britannica. Dalam: https://www.britannica.com/place/Saudi-Arabia [Diakses 21 Mei 2018].

The Economist. (2017). Saudi Arabia launches a futuristic economic zone. [online] Dalam: https://www.economist.com/middle-east-and-africa/2017/10/26/saudiarabia-launches-a-futuristic-economic-zone [Diakses 31 Mei 2018].

The National. (2017). SoftBank Vision Fund evaluates 'significant' Saudi Electricity stake acquisition. [online] Dalam: https://www.thenational.ae/business/ energy/softbank-vision-fund-evaluates-significant-saudi-electricity-stakeacquisition-1.670014 [Diakses 10 Juni 2018]. 
TRT World. (2018). Trump praises US military sales in talks with Saudi crown prince. [online] Dalam: https://www.trtworld.com/americas/trump-praises-us-militarysales-in-talks-with-saudi-crown-prince-16072 [Diakses 10 Juni 2018].

US News \& World Report. (2018). Power Rankings. [online] Dalam: https://www. usnews.com/news/best-countries/power-full-list [Diakses 21 Mei 2018].

Wagemakers, J. (2012). The Enduring Legacy Of The Second Saudi State: Quietist And Radical Wahhabi Contestations of Al-Wala Wa-L-Bara. Cambridge University Press: International Journal of Middle East Studies, 44, 93-110.

Yusufzai, R. (2001). Face to face with Osama. The Guardian, [online]. Dalam: https:// www.theguardian.com/world/2001/sep/26/afghanistan.terrorism3 [Diakses 4 Juni 2018]. 